\title{
Recomendaciones para el diagnóstico y tratamiento antimicrobiano de la rinosinusitis aguda bacteriana en pediatría
}

\section{Recommendations for diagnosis and antimicrobial treatment of acute bacterial rhinosinusitis in pediatrics}

\author{
Daniela Pavez, Regina Pérez, Jaime Rodríguez y José Cofré, en representación del \\ Comité de Antimicrobianos. Sociedad Chilena de Infectología. 2019
}

\author{
Correspondencia a: \\ Daniela Pavez Azurmendi \\ pavezdanita@gmail.com
}

\section{Introducción}

L a rinosinusitis aguda, definida como la inflamación de uno o más senos paranasales, es una afección frecuente en pediatría, presentándose como una complicación de infecciones respiratorias altas o es una manifestación de alergia respiratoria. Dado que su diagnóstico es eminentemente clínico, de vital importancia es el adecuado reconocimiento de una infección bacteriana o de su naturaleza alérgica para evitar el sobreuso de antimicrobianos, ya que corresponde a una de los principales motivos de prescripción de antibioterapia en pediatría ambulatoria.

\section{Definiciones}

Rinosinusitis aguda: Inflamación de la mucosa nasal y senos (o cavidades) paranasales. Puede ser de naturaleza infecciosa (viral o bacteriana) o alérgica o una combinación de ambas.

Rinosinusitis aguda bacteriana: Inflamación de la mucosa nasal y senos paranasales debido a infección bacteriana, secundaria a una infección respiratoria viral o alergia respiratoria. Se define arbitrariamente por síntomas catarrales y/o generales persistentes por más de 10 y menos de 30 días.

Rinosinusitis bacteriana subaguda: Definida por síntomas de más de 30 y menos de 90 días.

Rinosinusits bacteriana crónica: Persistencia de síntomas por más de 90 días, el paciente presenta síntomas respiratorios como tos, rinorrea y congestión nasal y alteraciones en imágenes de senos paranasales.

Rinosinusitis aguda recurrente: tres o más episodios de rinosinusitis aguda durante un período de 6 meses o más de 4 episodios en 1 año, con períodos asintomáticos de al menos 10 días.

\section{Epidemiología}

Las infecciones respiratorias altas, son muy frecuentes en los niños, quienes presentan aproximadamente 6 a 8 episodios al año. De ellos, entre 5 y 10\% cursará complicándose con una rinosinusitis aguda bacteriana.
Se estima, además, que 6 a 13\% de los niños a los 3 años de edad habrá presentado al menos un episodio de rinosinusitis bacteriana.

\section{Etiologías}

Establecer la etiología de una rinosinusitis bacteriana en Pediatría no es fácil, considerando que la vía respiratoria alta no es estéril y, para obtener una muestra bacteriológica representativa del proceso sinusal debiera efectuarse, idealmente, punción de las cavidades paranasales que sí, fisiológicamente, son consideradas estériles (ver párrafo sobre Estudio Microbiológico). Son escasos los estudios publicados que satisfacen este principio y, en general, la etiología de estos procesos se extrapola de los estudios bien reglados efectuados en otitis media aguda. En estas condiciones, se describen las siguientes etiologías:

- Comunes: Streptococcus pneumoniae, Haemophilus influenzae tipo b, Haemophilus influenzae no tipificables, Moraxella catarrhalis.

- Otras, de frecuencia imprecisa: Streptococcus pyogenes.

- Ocasionalmente Staphylococcus aureus, Streptococcus del grupo viridans ( $S$. anginosus, otros).

\section{Patogenia}

Hoy en día, sabemos que la rinosinusitis bacteriana puede ocurrir desde temprana edad. Esto debido a que los senos maxilares y etmoidales están presentes desde el nacimiento. El seno esfenoidal es neumatizado alrededor de los 5 años, y el frontal entre los 7 y 8 años, edades en que ya puede detectarse la complicación infecciosa de los mismos.

La rinosinusitis bacteriana se presenta como una complicación de una infección respiratoria alta viral. Está debidamente documentado que las IRAS altas de causa viral provocan lesión de la ultraestructura de los cilios respiratorios dificultando su función de arrastre y expulsión de agentes animados e inanimados de la superficie de la mucosa respiratoria (transporte muco- 
ciliar). El epitelio de la mucosa ciliar moviliza el exudado producido por los senos inflamados hacia el exterior de la nariz. Se explica así que en una infección viral del tracto respiratorio alto puede existir cierto grado de sinusitis sin ocurrir una sobreinfección bacteriana. Si la inflamación es intensa y prolongada en el curso de días, el edema mucoso puede obliterar el ostium y aislar los senos, limitando la remoción del exudado y favoreciendo la penetración de las bacterias residentes en la nasofaringe. Algo similar sucede en la alergia nasal. En suma, la rinosinusitis aguda bacteriana, debe entenderse como la sobreinfección bacteriana de un proceso inicialmente viral o alérgico.

\section{Manifestaciones clínicas}

La sintomatología de la rinosinusitis aguda bacteriana puede ser variada, y a veces, inespecífica; sin embargo, la principal característica es la persistencia de síntomas de infección respiratoria alta por más de 10 días y que no ha comenzado a mejorar.

La descarga nasal puede ser mucosa o purulenta, suele asociarse tos, seca o productiva, presente durante el día y que empeora durante la noche. Otro signo es la halitosis que en niños pequeños suele ser más marcada en el despertar matinal.

Síntomas como dolor facial y edema de párpados son poco frecuentes en niños. Generalmente, el niño no se ve con importante compromiso del estado general y la fiebre es baja. Ocasionalmente el cuadro sí adopta un carácter intenso, con fiebre alta, descarga nasal purulenta y compromiso mayor del estado general (Tabla 1).

\section{Criterios diagnósticos}

El diagnóstico de la rinosinusitis bacteriana aguda es clínico. Está basado principalmente en la temporalidad, en que el punto de corte para diferenciar una infección respiratoria alta no complicada versus una rinosinustis aguda se ha establecido en 10 días de evolución del cuadro.

La presencia de una rinorrea purulenta per se no hace diagnóstico de rinosinusitis bacteriana a menos que se considere el factor de temporalidad antes mencionado.

Sospecharemos una rinosinusitis bacteriana aguda frente a las siguientes situaciones clínicas:

- Evolución tipo A: catarro nasal/tos persistentes, con descarga nasal y/o tos diurna que se prolongan por al menos 10 días sin mejoría.

- Evolución tipo B: empeoramiento o nueva aparición de descarga nasal, tos o fiebre luego de una mejoría transitoria. Es decir, infección respiratoria alta que mejora a los 3-4 días, pero que empeora dentro de los 10 días del inicio del cuadro.
- Evolución tipo $C$ : sintomatología intensa, con fiebre elevada (más de $39^{\circ} \mathrm{C}$ ), compromiso del estado general, cefalea, descarga nasal purulenta por al menos tres días consecutivos.

\section{Utilidad de la imagenología en el diagnóstico de rinosinusitis aguda}

No son necesarias las imágenes para el diagnóstico de la rinosinusitis aguda bacteriana no complicada, su uso se reserva sólo frente a la sospecha de complicaciones (compromiso orbitario o del SNC). Es más, tanto la radiología simple como la tomografía computada de cavidades paranasales tienen un pobre valor predictor positivo.

- Rx cavidades paranasales: Imágenes pueden sub o sobre estimar alteraciones. Los individuos sanos pueden presentar alteraciones sugerentes de rinosinusitis, al mismo tiempo que imágenes patológicas (ocupación de espacio aéreo, engrosamiento de la mucosa sinusal) pueden ser encontradas dos o más semanas después de una infección respiratoria alta. Cincuenta por ciento de los niños con infecciones respiratorias altas presentan alteraciones en senos maxilares, por lo que la radiografía no ayuda a diferenciar entre sinusitis bacteriana o infecciones virales.

- Tomografía computada de cavidades paranasales: se reserva para las rinosinusitis agudas graves, complicadas, o formas extremadamente resistentes a tratamiento. Es frecuente observar alteraciones en la TC en pacientes sanos; se ha comprobado, además, en pacientes recuperándose de un resfrío común, alteraciones significativas en senos maxilares, hasta en $87 \%$ de los casos. Por esto tampoco tiene utilidad en diagnóstico de sinusitis aguda bacteriana no complicadas.

\section{Otros elementos de diagnóstico}

- Nasofibroscopia: es un test diagnóstico simple y completo que permite objetivar la infección de senos paranasales. Permite, además, evaluar el tamaño ade-

Tabla 1. Síntomas y signos presentes en la rinosinusitis aguda bacteriana Síntomas y signos leves Síntomas y signos mayores Rinorrea mucosa o purulenta Fiebre elevada (más de $39^{\circ} \mathrm{C}$ ) Tos diurna Rinorrea purulenta copiosa y persistente Fiebre de baja cuantía Tos diurna y nocturna Halitosis Edema periorbitario Cefalea

Compromiso del estado general 
noideo y revelar posibles infecciones como adenoiditis, examinar el septo nasal, meatos medio e inferior y rinofaringe, siendo posible identificar inflamación o descarga purulenta en sitios de drenaje de los senos paranasales, hallazgo que confirma el diagnóstico. Tiene como ventaja, además, permitir la identificación de anormalidades anatómicas. Este examen es realizado por otorrinolaringólogo.

- Cultivo nasal: (secreción nasal o recolección con hisopos) no se recomienda de rutina. Estudios comparativos con punción de seno maxilar, encontraron una concordancia entre los agentes hallados en las secreciones sinusales y nasales en sólo $64 \%$, indicando que las muestras nasales reflejan escasamente cuál es el agente causal de la infección sinusal.

- Cultivo de meato medio: dirigido en forma endoscópica, muestra una sensibilidad de $81 \%$ y especificidad de $91 \%$ al ser comparados con el estándar de oro, la punción de seno paranasal; es una alternativa para aquellos pacientes en que sea imperiosa la búsqueda del agente etiológico. Para hacer diagnóstico de sinusitis aguda el cultivo debe mostrar la presencia de más de $10^{4}$ unidades formadoras de colonias $/ \mathrm{ml}$.

- Punción de senos paranasales: es un procedimiento invasor; se debe limitar su empleo al paciente inmunocomprometido y, ocasionalmente, al paciente con fibrosis quística. No se recomienda como método diagnóstico de rutina en niños.

\section{Complicaciones}

Las infecciones sinusales, en caso de un tratamiento tardío o inadecuado, pueden diseminarse a estructuras vecinas. Estas complicaciones son poco frecuentes, pero pueden ser graves.

Las estructuras más frecuentemente afectadas son:

- Compromiso orbitario: celulitis pre y post septal, absceso sub-perióstico, absceso orbitario, trombosis de seno venoso. La complicación más frecuente es la celulitis periorbitaria preseptal secundaria a etmoiditis; con mayor frecuencia se observa en lactantes y pre-escolares. Se manifiesta como un aumento de volumen palpebral, unilateral, con carácter inflamatorio, sin secreción ocular en sus estadios iniciales. Su reconocimiento tardío puede favorecer la evolución hacia un compromiso retroseptal. Como contrapartida, la celulitis retroseptal es más propia de escolares y se reconoce por los siguientes síntomas: oculalgia, visión borrosa, diplopía, proptosis y estrabismo; constituye una emergencia médica $\mathrm{y}$, a veces, quirúrgica.

- Compromiso del sistema nervioso central: empiema subdural y epidural, meningitis, absceso cerebral.

\section{Manejo general del paciente}

La sinusitis aguda bacteriana no complicada es de manejo ambulatorio, con excepción de aquellos pacientes que evolucionan con intensos síntomas, que pueden requerir analgesia y antibioterapia, inicialmente, por vía parenteral. Con alguna frecuencia, el diagnóstico no es patente y el paciente es internado para estudio de un episodio febril sin foco o una cefalea invalidante. En estos casos, una anamnesis dirigida (no inducida) y, eventualmente, la evaluación por el otorrinolaringólogo (sin recurrir erróneamente al estudio por imágenes), podrán confirmar la presencia de un foco sinusal.

La sinusitis complicada y su sospecha son indicación de internar al paciente para completar su evaluación imagenológica y efectuar antibioterapia parenteral. En estos casos, es mandatorio evaluar al paciente con una TC de senos paranasales y, según sus hallazgos, solicitar el concurso de oftalmología y/u otorrinolaringología.

\section{Tratamiento antimicrobiano}

Se recomienda tratar a aquellos pacientes con sintomatología intensa o con empeoramiento (evoluciones tipo B y C). Aquellos pacientes que sólo presenten curso con rinorrea persistente más de 10 días (evolución tipo A) se pueden dejar sin antimicrobianos, en observación por $72 \mathrm{~h}$ y reevaluar al cabo de ese plazo. Al respecto, revisiones Cochrane en los años 2002 y 2007 concluyen que una terapia de 10 días es útil en reducir la probabilidad de rinorrea persistente a corto y mediano plazo; sin embargo, se requiere tratar a ocho niños para obtener un caso de recuperación.

Considerando las etiologías más frecuentes de la rinosinusitis aguda bacteriana, los fármacos de elección son:

\section{Terapia oral}

(Todos los esquemas a continuación deben ser prescritos durante 10 días; no hay evidencia en niños de obtener igual beneficio mediante esquemas acortados).

- Primera línea: amoxicilina en dosis de $50 \mathrm{mg} / \mathrm{kg} /$ día fraccionada cada $12 \mathrm{~h}$. Cabe destacar que según datos del Instituto de Salud Pública (ISP), Streptococcus pneumoniae, tiene una resistencia a macrólidos y azálidas de aproximadamente $30 \%$, llegando a ser, en algunos grupos etarios, cercana a $50 \%$, por lo que no debe utilizarse como terapia de primera línea.

- Segunda línea: amoxicilina/ácido clavulánico: 70$90 \mathrm{mg} / \mathrm{kg} /$ día. Mejora actividad sobre Haemophilus influenzae b y no tipificables, (cepas productoras de $\beta$-lactamasa). Dosis mayores de amoxicilina podrían optimizar su farmacodinamia. 
Alternativa: Cefuroxima axetil $30 \mathrm{mg} / \mathrm{kg} /$ día fraccionado cada $12 \mathrm{~h}$. Mejora actividad sobre Haemophilus influenzae b y no tipificables, (cepas productoras de $\beta$-lactamasa), pero disminuye actividad sobre $S$. pneumoniae.

Cloranfenicol: es una alternativa eficaz y económica, con buena actividad sobre las principales etiologías de rinosinusitis aguda; lamentablemente es de escasa disponibilidad en el comercio. Dosis: $50 \mathrm{mg} / \mathrm{kg} /$ día fraccionado cada 6 a $8 \mathrm{~h}$.

Cefalosporinas de tercera generación oral no tienen beneficios en cobertura frente a amoxicilina/clavulánico, ya que no optimizan actividad sobre cepas de $S$. pneumoniae resistentes.

Quinolonas: su registro en el ISP no aprueba su uso en pacientes bajo 18 años de edad.

\section{Terapia parenteral}

- Ampicilina/sulbactam $100 \mathrm{mg} / \mathrm{kg} /$ día, fraccionada cada $6 \mathrm{~h}$.

- Ceftriaxona: $50 \mathrm{mg} / \mathrm{kg} /$ día en una dosis diaria o cefotaxima: $100 \mathrm{mg} / \mathrm{kg} /$ día en tres a cuatro dosis diarias. Se debe aumentar estas dosis en caso de compromiso de sistema nervioso central. Reservadas para las formas complicadas de sinusitis; en estas circunstancias, considere la asociación de terapia anti-estafilocócica (cloxacilina, clindamicina o cotrimoxazol; estas dos últimas están recomendadas si hay sospecha de $S$. aureus resistente a cloxacilina-adquirido en la comunidad), si se ocuparán cefalosporinas de tercera generación.

- Duración del tratamiento: 10 a 14 días o más, según la magnitud y ubicación de la complicación infecciosa. Puede efectuarse cambio a terapia oral según sea la respuesta clínica, en forma individualizada.

\section{Terapia adyuvante}

El uso de mucolíticos descongestionantes y expectorantes no ha demostrado beneficio adicional a la antibioterapia en la recuperación de una rinosinusitis aguda bacteriana.

El uso de corticosteroides nasales sí puede otorgar un beneficio adicional si es que hay sospecha o evidencia de rinosinusitis alérgica. El uso de antihistamínico ha mostrado un efecto similar al uso de un placebo.

\section{Recomendaciones finales}

Ver Tabla 2.

Tabla 2. Recomendaciones finales en rinosinusitis aguda bacteriana

Recomendaciones
El diagnóstico de la rinosinusitis aguda es clínico
El diagnóstico se realiza en las siguientes situaciones:
- Enfermedad persistente, con descarga nasal y/o tos diurna que
se prolongan por al menos 10 días sin mejoría
- Curso con empeoramiento o nueva aparición de descarga nasal,
tos o fiebre luego de una mejoría previa
- Sintomatología intensa, fiebre y descarga nasal purulenta por al
menos tres días consecutivos

\section{Errores frecuentes}

Tomar exámenes como radiografía o TC de cavidades paranasales para el diagnóstico

Tomar cultivo nasal para adoptar conducta terapéutica

El tratamiento se debe indicar a los pacientes cuyo curso muestra empeoramiento o es muy intenso

En con pacientes con síntomas leves pero persistentes se puede observar evolución por 72 h y controlar

El tratamiento de primera línea es amoxicilina en dosis habituales

Uso de cefalosporinas de primera generación como cefadroxilo o macrólidos y azálidas (azitromicina) para el tratamiento

Alternativas de segunda línea son amoxicilina/ác. clavulánico,

cefuroxima

En alergia tipo 1 (anafilaxia): macrólidos, azalida o cloranfenicol.

En alergia no tipo 1: cefuroxima

No se recomienda el uso de cefalosporinas de tercera generación ni

quinolonas en sinusitis aguda no complicada 


\section{Lecturas recomendadas}

\section{Artículos de revisión}

- Wald E R. Sinusitis in children. Current concepts. N Engl J Med 1992; 326 (5): 319-23. DOI: 10.1056/ NEJM199201303260507.

- Novembre E, Mori F, Pucci N, Bernardini R, Vierucci A, de Martino R. Systemic treatment of rhinosinusitis in children. Pediatr Allergy Immunol 2007: 18 (Suppl 18): 56-61. https://doi.org/10.1111/j.13993038.2007.00636.x.

- Brook I. Current issues in the management of acute bacterial sinusitis in children. Intern J Pediatr Otorhinolaryngol 2007; 7: 1653 -61.https://doi.org/10.1016/j. ijporl.2007.06.012.

- Guarch Ibáñez B, Buñuel Álvarez J C, López Bermejo A, Mayol Canals L. El papel de la antibioterapia en la sinusitis aguda: revisión sistemática y meta-análisis. An Pediatr (Barc) 2011; 74 (3): 154-60. DOI: 10.1016/j.anpedi.2010.10.011.

- Brook I. Acute sinusitis in children. Pediatr Clin North Am 2013; 60: 409-24. DOI: 10.1016/j.pcl.2012.12.002.

- Esposito S, Bosis S, Bellasio M, Principi N. From clinical practice to guidelines: how to recognize rhinosinusitis in children. Pediatr Allerg Immunol 2017: 18 (Suppl 18): 53 -5. DOI: 10.1111/j.13993038.2007.00635.x

\section{Guías clínicas}

- Klossek J M, Federapil P. Update on treatment guidelines for acute bacterial sinusitis. Int J Clin Pract 2005; 59 (2): 230-8.https://doi.org/10.1111/j.17421241.2005.00378.x.

- Esposito S, Principi N. Italian Society of P, Italian Society of Pediatric I, Italian Society of Pediatric A, Immunology. et al. Guidelines for the diagnosis and treatment of acute and subacute rhinosinusitis in children. J Chemother 2008; 20 (2): 147-57. DOI: 10.1179/ joc.2008.20.2.147.

- Desrosiers M, Evans G A, Keith P K, Wright E D, Kaplan A, Bouchard J, et al. Canadian clinical practice guidelines for acute and chronic rhinosinusitis. Asthma Clinl Immunol 2011; 7: 2. https://doi. org/10.1186/1710-1492-7-2.

- Chow A W, Benninger M S, Brook I, Brozek J L, Goldstein E J C, Hicks L A, et al. IDSA Clinical practice guideline for acute bacterial rhinosinusitis in children and adults. Clin Infect Dis 2012; March 20, 2012. https://www.idsociety.org/uploadedFiles/IDSA/ Guidelines-Patient_Care/PDF_Library/IDSA\%20 Clinical\%20Practice $\% 20$ Guideline $\% 20$ for $\% 20$ Acute $\% 20$ Bacterial\%20Rhinosinusitis\%20in\%20 Children\%20and\%20Adults.pdf 